\title{
URBAN AGRICULTURE AS A SUSTAINABLE OPTION FOR SOLID WASTE MANAGEMENT: CASE STUDY OF AN INDIAN CITY
}

\author{
HARI PRASAD AGARWAL, SUCHANDRA BARDHAN \& DEBASHISH DAS \\ Department of Architecture, Jadavpur University, India
}

\begin{abstract}
The rapid growth of India's urban population coupled with food security concerns has driven urban agriculture into Indian cities. It is also commonly known that urban local bodies are struggling with the ever-increasing municipal solid waste, and in managing its segregation, transportation, and treatment. Inadequate organic waste management causes a slew of issues like gas emissions and health risks to the community. Since household wet wastes are full of nutrient-rich organic matter favorable for growing plants, urban agriculture provides an excellent opportunity of bridging the gap by reimagining waste as a resource. This study is based on the premise that decentralized urban waste management can be achieved through reusing and recycling organic waste that can benefit urban food production. It has conducted a qualitative and quantitative assessment of the organic waste usage in urban agriculture in the Indian city of Mumbai, Maharashtra. This paper presents the results of the study and examines the existing and potential capacity of urban agriculture in consuming organic urban waste in Mumbai's context. This case study also helps in visualizing circular economy against a real-life urban scenario and how the production-consumption loop may gainfully sustain each other. Based on the learning, the paper recommends mainstreaming urban agriculture into the sustainable city framework.

Keywords: compost, organic waste, recycling, solid waste management, urban agriculture.
\end{abstract}

\section{INTRODUCTION}

Urban populations are growing rapidly worldwide [1], [2], adding a strain on existing waste collection and disposal infrastructure [3], [4]. Research has shown that billions of tons of waste are produced annually by municipalities and industries the world over [5]. In India, no city can claim to have $100 \%$ trash segregation at the household level, and on average, only $70 \%$ of waste is collected, with the remaining 30\% gets absorbed by the urban system. Again, just $12.45 \%$ of the garbage collected is scientifically processed, while the rest is dumped in open landfills [6]. In India, 90\% of municipal solid waste (MSW) produced is disposed of in landfills and/or open dumps [7]. Furthermore, unscientific and conventional waste disposal practices such as open dumping and burning not only pollute the environment and degrade the city landscape but also hinder long-term, environmentally responsible waste management [8]. In addition to endangering the environment's quality (land, air, and water pollution) and community health, landfills also result in the depletion of nutrients contained in the waste, which is a financial loss [9], [10]. Landfills may also trigger fire hazards, as had happened in the Deonar landfill, the 132-hectare largest garbage dump in Mumbai receiving around 4,000-5,000 tonnes of waste/day. It had caught a severe fire in January 2016 that lasted for more than four days [11].

Environmental experts and activists began to criticize waste management practices in the mid-1970s. As a more effective management system, a waste management hierarchy was devised [12], [13]. This is indicated in Fig. 1 and can be described as "all actions taken to reduce the negative environmental impact of waste by reusing, recycling, and recovering resources before final disposal" [14]. 


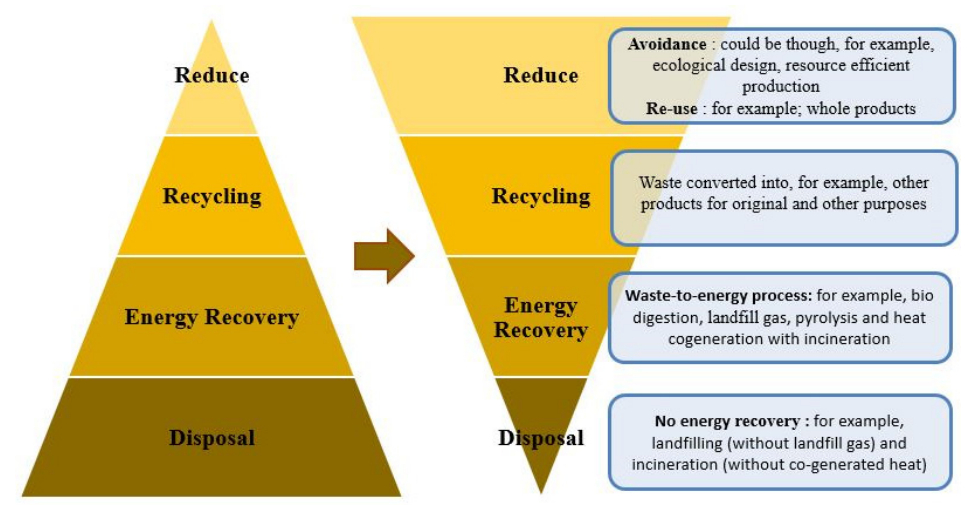

Figure 1: Effective hierarchy of waste management model [14].

By reversing the behaviours at the top and bottom of the hierarchy of waste management, those at the top (reduce, reuse, recycle) are given priority [15], [16]. The main idea is that preventing waste is more efficient than reusing, which is better than recycling, and recycling, in turn, is better than incineration or landfilling [12], [14]. Thus, urban agriculture offers opportunities for using recycled organic waste to power local food production. By utilizing nutrients from composted waste, it has the potential to help cities close the productionconsumption loop and transition from "plate-to-landfill" to "plate-to-plate" practices.

The current study is based on this very idea of reusing organic waste after source segregation and recycling it for urban agriculture (UA) in the Indian city of Mumbai, Maharashtra. The objectives of the study are to understand the solid waste management practices of the residential communities that reuse their kitchen waste in their own kitchen gardens, assess the annual quantities at the different stages of the waste-to-compost process, and finally, examine the potential capacities of urban agriculture in consuming organic urban waste based on these results.

\section{LITERATURE STUDY}

The literary and scholarly works of organic waste management integration with UA in India and other countries were studied to understand its various dimensions. Studies on Mumbai city were taken up first. The generation of MSW in Mumbai is very high, which is about 7,000 metric tonnes per day [17]. In India, about $40-60 \%$ of MSW in urban areas consists of compostable organic materials [7], [18]. It was estimated that Mumbai generates $62 \%$ of organic waste, the largest volume of urban organic waste in India [19]. Composting is an easy and cost-effective technology for treating the large organic fraction of MSW produced in Indian cities, due to the high proportion of biodegradable, organic waste generated [18], [20]. By conducting proper composting after suitable segregation, the final waste volumes are stated to be reduced by $50-85 \%$ [7]. Thus, appropriate composting will minimize the load for collection and transportation, as well as the burden on landfills [7], [19]. Integration of waste management with UA can be seen as one of the most environment-friendly and sustainable alternatives to conventional waste disposal and energy recovery methods [21]. MSW usually contains a high amount of organic material and nutrients that can be used as a fertilizer in urban agriculture. Rooftops, backyards, pot culture, and any small parcel of open spaces can be used for food production [22]. UA can also ensure a resilient urban food system as dependence on external imports can be reduced during exigencies. This is exemplified 
during World War II in the United States when families planted Victory Gardens producing $55 \mathrm{~kg}$ of fruit and vegetables annually [23]. Similarly, after the fall of the Soviet Union in Cuba, the government set a goal of cultivating $10 \mathrm{~m}^{2}$ of urban land for every resident to address the public health issues. The country achieved sufficiency in food production by 2,000 with the urban farms providing up to $50 \%$ of caloric intake, thus reducing fuel consumption for food distribution and refrigeration [24]. It is compatible with green energy harvesting from organic waste and can also give other benefits to the circular economy (as indicated in Fig. 2), including job opportunities [25].

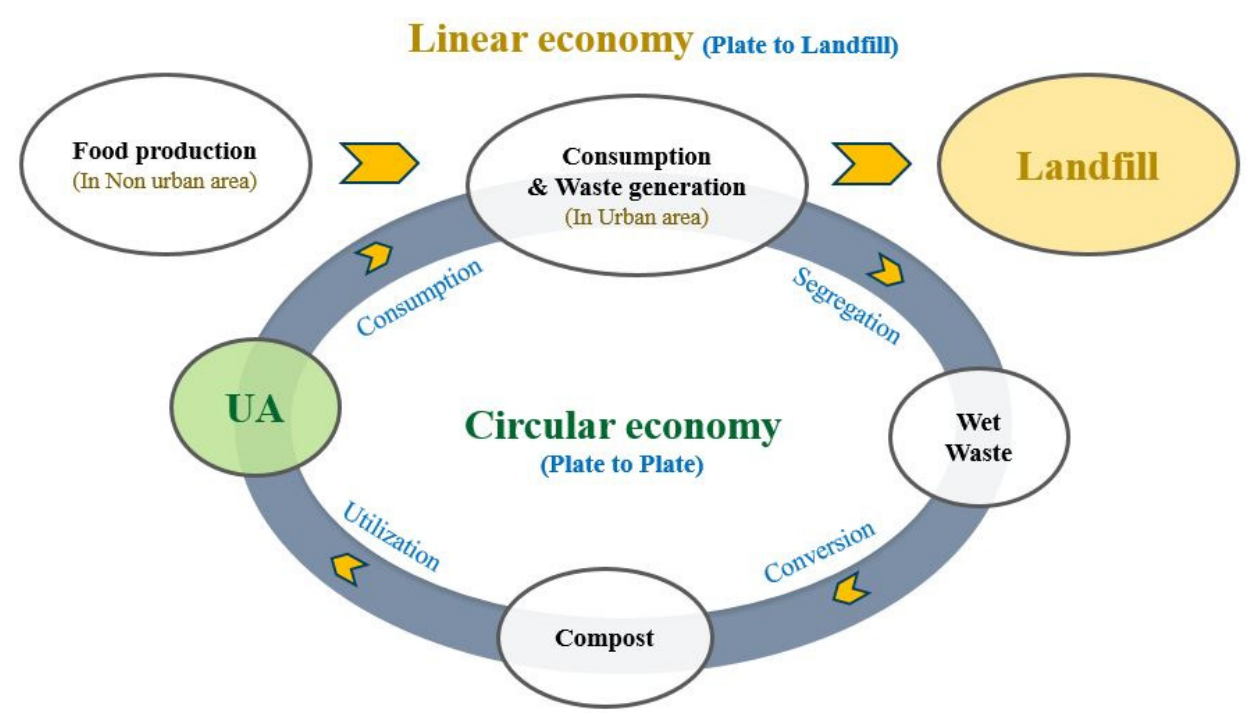

Figure 2: Circular economy with solid waste management along with UA.

Since India is an agrarian nation, UA had long been a household tradition that began with the management of kitchen food waste, but it slowly got lost in the current patterns of urbanization. Some of the UA initiatives that have succeeded in Mumbai are the International Institute of City Farming founded by Dr. Doshi in 1994, Urban leaves, Green souls, Fresh and local, Swachha Parle Abhiyan, and others [26]. Studies have argued in favour of local bylaws for the regulation and evaluation of conforming measures, such as source separation of garbage or penalties for public dumping, to promote "best practices" in waste management. Compost being an agricultural input, the Ministry of Food and Agriculture may prepare quality standards, marketing plans, and relevant policies. Linking urban and periurban agriculture to urban management through the composting of urban trash can improve the urban environment while also providing a beneficial product for farmers [27]. It is also believed that the installation of decentralized solid waste processing units in metropolitan cities/towns and the development of the formal recycling manufacturing industry are essential in developing countries like India [28].

\section{MATERIALS AND METHODS}

The literature review was followed by the preparation of a theoretical framework for the study with the relevant qualitative and quantitative aspects of waste management and UA. Each of these is further classified into sub-aspects. The aspect of resources is quantitative. 
The framework is presented in Table 1. The specific case studies in Mumbai were then identified. The data collected was processed and collated thereafter for scientific reporting, as presented in this paper.

Table 1: Theoretical framework of the study.

\begin{tabular}{|c|c|}
\hline Aspects & Sub-aspects \\
\hline \multicolumn{2}{|l|}{ A. Qualitative } \\
\hline \multirow{3}{*}{$\begin{array}{l}\text { Segregation of solid } \\
\text { wastes }\end{array}$} & a. Wet/Biodegradable/Organic waste \\
\hline & b. Dry/Non-biodegradable waste \\
\hline & c. Domestic hazard waste \\
\hline \multirow{4}{*}{$\begin{array}{l}\text { Conversion of organic } \\
\text { kitchen waste into } \\
\text { compost }\end{array}$} & a. Aerobic composting \\
\hline & b. Vermicomposting \\
\hline & c. Anaerobic composting (Bokashi) \\
\hline & d. Anaerobic digester \\
\hline \multirow{4}{*}{$\begin{array}{l}\text { The utilization of this } \\
\text { compost in UA in the } \\
\text { same premises }\end{array}$} & a. Within premises - Rooftop \\
\hline & b. Within premises - Balcony/window sill \\
\hline & c. Within premises - Campus landscapes \\
\hline & d. Community gardens \\
\hline \multicolumn{2}{|l|}{ B. Quantitative } \\
\hline \multirow{3}{*}{$\begin{array}{l}\text { Resources: Quantitative } \\
\text { measures of the above }\end{array}$} & Average annual organic waste generated (tonnes/year) \\
\hline & Average annual compost produced (tonnes/year) \\
\hline & $\begin{array}{l}\text { Average annual compost utilized (tonnes/year) in Rooftop } \\
\text { farming }\end{array}$ \\
\hline
\end{tabular}

\subsection{Selection of case studies}

Mumbai is the state capital of Maharashtra, one of the megacities of India and the financial capital of the country. It is well connected, well developed, and densely populated. A total of 22 case studies covering 21 co-operative housing societies and one community farm were studied at Vile Parle-East, Ward-KE (sub-divisions 84 and 85) of Brihanmumbai Municipal Corporation (BMC), Mumbai. The population density of the ward is between 26,518-54,296 persons $/ \mathrm{km}^{2}$ [29], [30]. The coming into force of the solid waste management rules in 2016 along with the implementation of the Mumbai Municipal Corporation (MMC) Act, 1888 and Greater Mumbai Cleanliness and Sanitation Bye-laws, 2006 [31]-[33] has resulted in a marked improvement of waste management in the city of Mumbai. The combination of strict penalties and generous rewards of rebates in property taxes has brought the change. The ward KE was chosen as the majority of its housing societies have implemented "good practices" very successfully with the help of an organization named "Swachha Parle Abhiyan", a community farm that has trained and inspired many people of the neighborhood to compost their organic waste and utilize it for UA. They have been widely recognized and rewarded by the Municipal Corporation and other public forums for setting an excellent example of closing the material cycling loop by completing the entire process of waste segregation, composting organic waste, and utilizing the same for growing vegetables in the same premises. The 21 housing societies house 1,328 families, out of which 1,177 (about 89\%) households practice waste segregation. The waste management practices of these 1,177 households spread over these 21 co-operative housing societies (CHS) were surveyed. These case studies are named CHS 1, CHS 2, and so on, till CHS 21, and their locations are marked in the ward map in Fig. 3. 


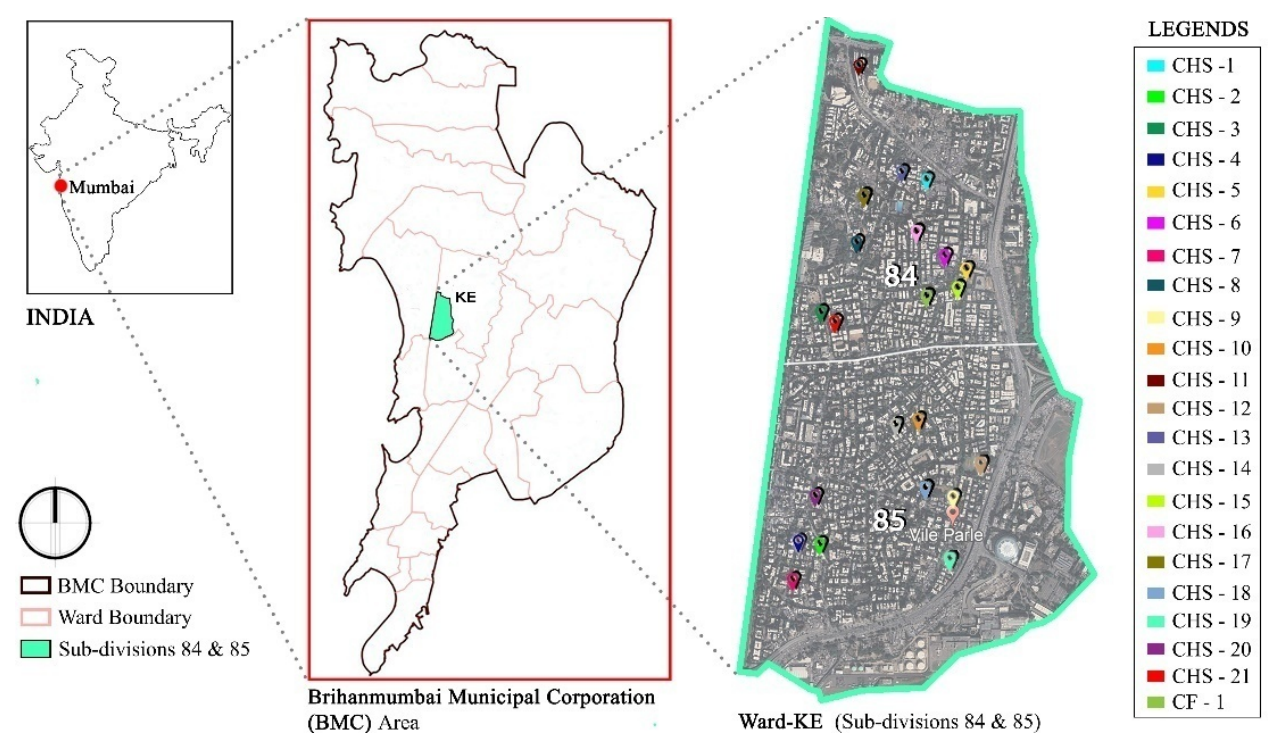

Figure 3: Map showing the locations of the case studies in the KE Ward, Mumbai.

\subsection{Methods of data collection}

A detailed field survey through an in-depth interview with the key informants, where applicable, was conducted from January to March 2021. The open-ended questionnaire was designed based on the theoretical framework. The interviews focussed on their organic waste management practices, the challenges faced and the benefits obtained by integrating their organic kitchen waste with urban agriculture in a decentralized manner. The relationships between segregation-conversion-utilization of organic kitchen waste and urban agriculture as observed in the case studies are expressed in Fig. 4.

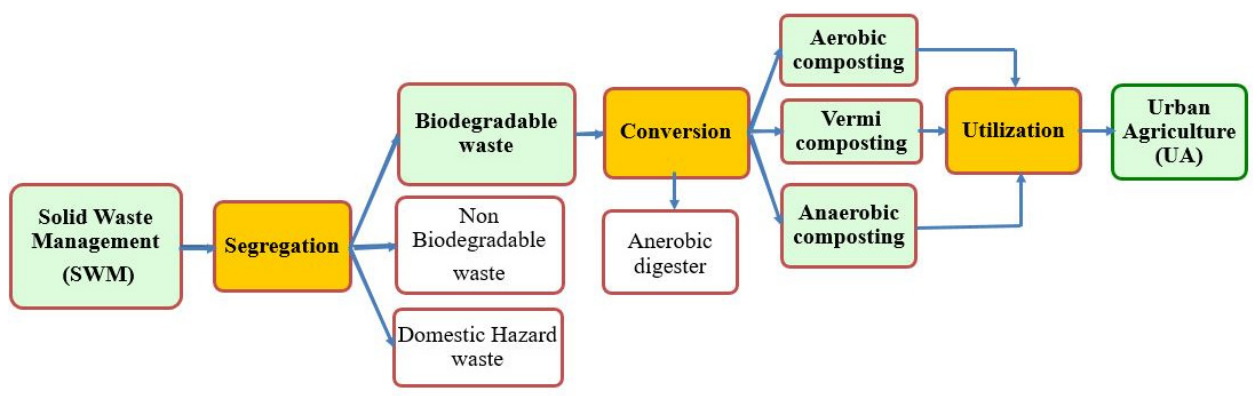

Figure 4: A conceptual system of solid waste management along with UA.

Primary data was also collected through field observations, photo documentation, and informal discussions. Important information was obtained on methods for conversion of segregated organic waste (composting, vermicomposting, and anaerobic digester), innovative techniques applied in the converted compost in UA. The interviewees were members of the 
1,177 households within the housing societies who were practicing some form of organic waste management with urban agriculture at the time of the study. Other informants consisted of solid waste management (SWM) experts, environmental engineers, architects, staff of the cleaning and solid waste department, and UA practitioners.

\section{RESULTS AND DISCUSSIONS}

All data collected on the case studies are arranged in two sections: (i) qualitative and (ii) quantitative. The quantitative section further presents a projection of five potential benefits that can be accrued from urban agriculture practiced in the form of rooftop farming. This is based on the amounts of organic waste obtained through the survey.

\subsection{Qualitative findings}

The qualitative findings have been organized under the previously mentioned three aspects of SWM: (a) segregation of solid waste; (b) conversion of organic waste into compost; and (c) utilization of compost for farming. Remarks and observations are written against each aspect.

4.1.1 Overall segregation, conversion, and utilization scenario in the case studies

All the case studies are following the three stages of SWM i.e. segregating the wet waste, converting it into compost, and utilizing it on the same premises, although partial in some cases. It is also found that $86 \%$ of the case studies (18) are utilizing their compost within their housing premises. This is depicted in Fig. 5.

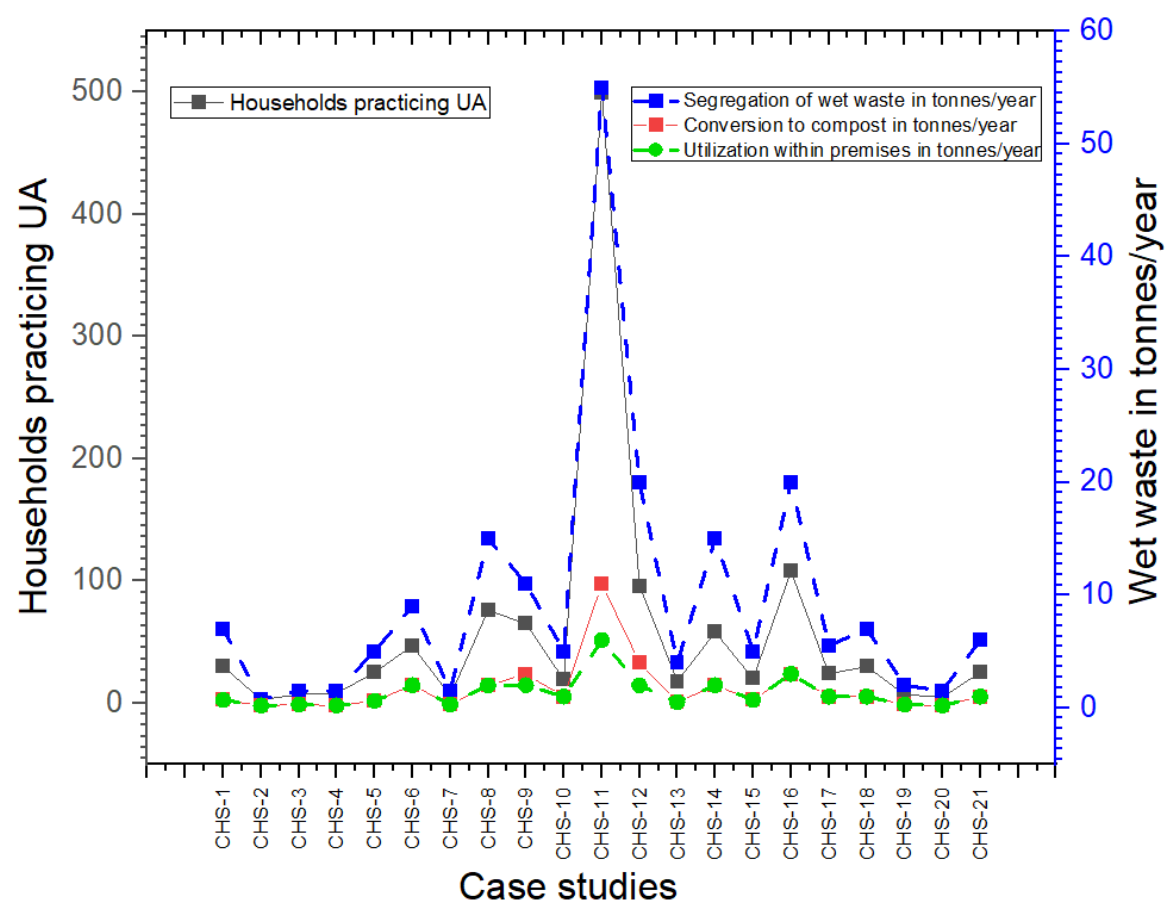

Figure 5: Number of households in the case studies who practice UA with segregation, conversion, and utilization. 
4.1.2 Conversion of organic waste to compost scenario

As shown in Fig. 6, 81.05\% (15) are using the aerobic method, 11.81\% (4) using vermicomposting and only $7.14 \%$ (2) are using anaerobic (Bokashi) methods for composting.

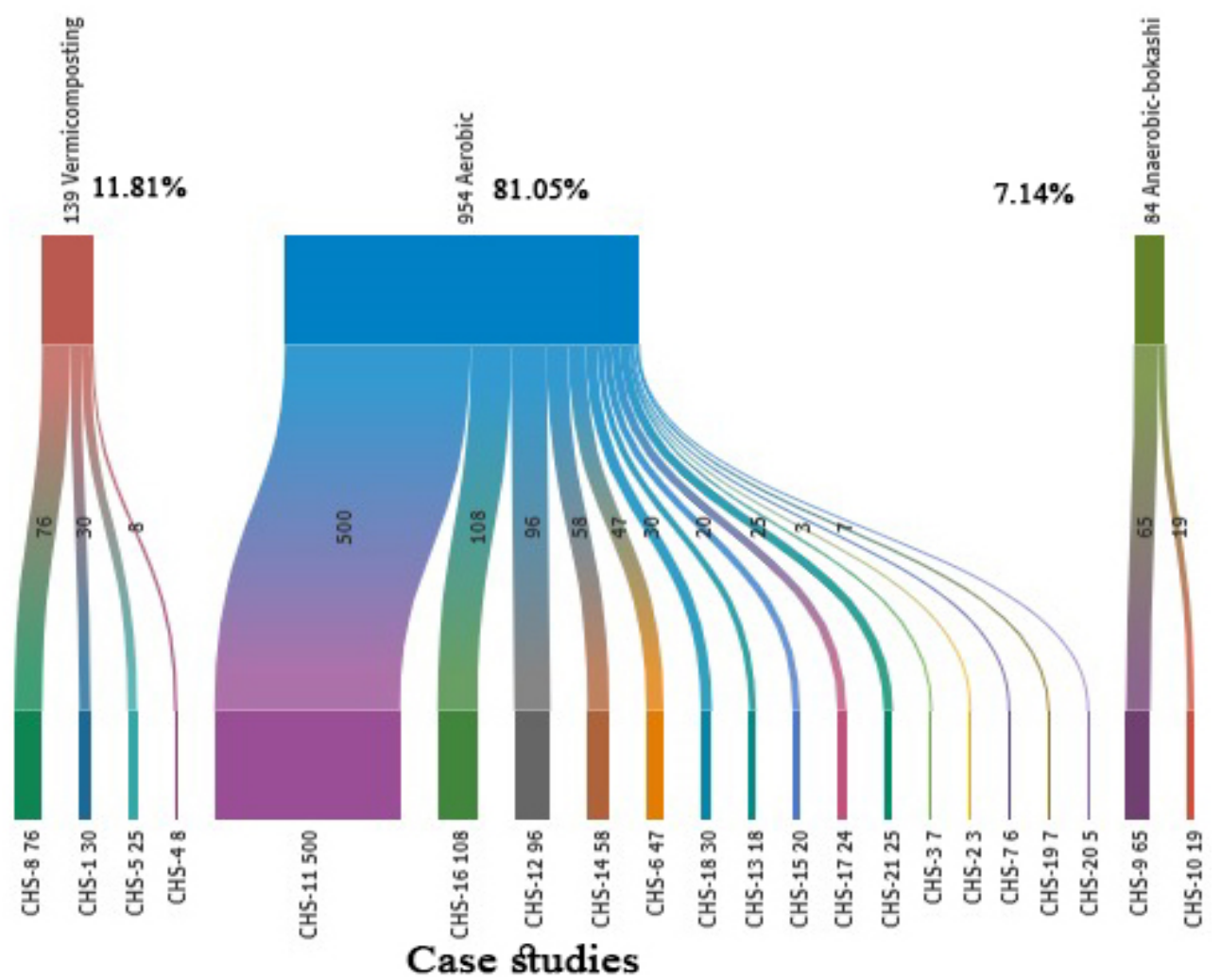

Figure 6: Percentage breakup of the conversion of segregated wet waste into compost.

\subsubsection{Utilization of the compost in UA through the roof, balcony, and} community gardens

At the utilization stage, it is found that only $38 \%$ of the case studies (8) are utilizing the compost for rooftop farming (RTF) and the remaining $62 \%$ (13) are using their compost for their balcony plant pots or campus landscapes, and as mentioned earlier, 14\% (3) are utilizing the compost for the community gardens. This is indicated in Fig. 7.

\subsection{Quantitative findings}

The quantitative study looked into the average annual wet waste usage pattern for the 1,177 households within the 21 housing societies:

a. Average annual organic waste generated $=198$ tonnes $/$ year.

b. Average annual compost produced $=35$ tonnes/year.

c. Average annual compost utilized for rooftop farming $=7$ tonnes/year (on cultivating area of $\left.280 \mathrm{~m}^{2}\right)$. 


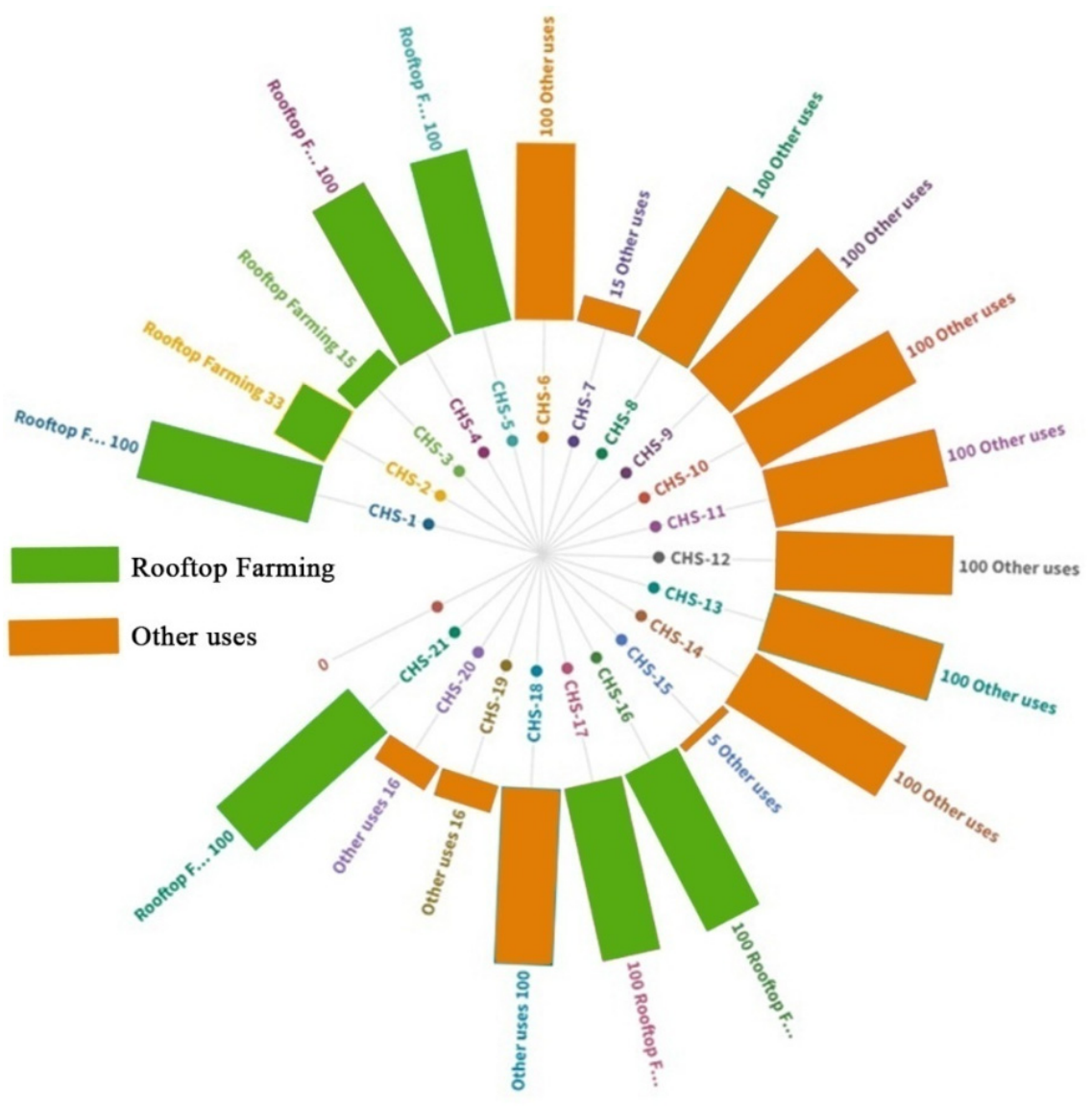

Figure 7: Percentage breakup of the utilization of compost in UA.

4.2.1 Proposed model with the projection of potential benefits through rooftop farming

1. Based on the above survey findings of the 1,177 households, a typical seven-story building with a similar number of households is assumed in the same municipal ward of Mumbai. Considering $50 \mathrm{~m}^{2}$ of floor area per household and 168 households/floor, the rooftop area works out as $8,400 \mathrm{~m}^{2}$. It was further assumed that $40 \%$ of this rooftop would be designated for social purposes and the remaining $60 \%$ or $5,040 \mathrm{~m}^{2}$ would be used for rooftop farming (RTF). Again, $80 \%$ of this RTF area would be used for actual farming i.e. $4,032 \mathrm{~m}^{2}$ is the net cultivable area.

2. In absence of any published work on the valuation of RTF benefits in India, the methodologies and standard values for their estimation are derived from a Canadian study [34]. The five-point potential benefits of RTF based on this study are: property value increase, food production, stormwater retention, air quality improvement, and carbon sequestration. All the values are calculated in Indian currency (where $1 \$=$ Rs. $74.35 /-$, based on the rate of 30 August 2021). The details of the calculation of such benefits for the assumed seven-story building with net cultivable area of $4,032 \mathrm{~m}^{2}$ are as follows. 
4.2.1.1 Property value, $b_{1}=0.07 \times v$

In this formula, " $b_{1}$ " denotes the value of the benefit and "v" presents the value of the RTF host property.

As RTF enhances the worth of a property as well as the marketability of surrounding properties, it favors both the owner and the environment. The property worth of a building with a green roof rises by $7 \%$ if it is efficient and by $11 \%$ if it is recreational. This is substantial considering the rising real estate values of the area.

$\mathrm{b}_{1}=0.07 \times \mathrm{v}\left(\right.$ per $\mathrm{m}^{2}$ of carpet area $) \times 4,032 \mathrm{~m}^{2}=0.07 \times 4,707.46 \$ / \mathrm{m}^{2} \times 4,032 \mathrm{~m}^{2}=$ $1,328,633.51$ \$ (Rs. 98,783,901/-)

4.2.1.2 Food production value, $\mathrm{b}_{2}=\mathrm{P} \times \mathrm{g} \times \mathrm{a}$

In this formula, $\mathrm{P}=$ productivity ( $\$ 2$ per $\mathrm{m} 2$ per month and for lettuces, herbs, and flowers (high case scenario) $\$ 20$ per $\mathrm{m}^{2}$ per month), $\mathrm{g}=$ duration of growing; as crops were grown all the year so it is taken as 12 months and a = roof area covered by farming.

As in Indian cities, crops are grown all over the year and the RTF mostly produces both vegetables and fruits, so the total worth of production is likely to be at the lower end of this range i.e. $\$ 2$ per $\mathrm{m}^{2}$ per month.

$$
\mathrm{b}_{2}=\mathrm{P} \times \mathrm{g} \times \mathrm{a}=2 \$ / \mathrm{m}^{2} / \mathrm{month} \times 12 \text { months } \times 4,032 \mathrm{~m}^{2}=96,768 \$(\text { Rs. } 7,194,701 /-)
$$

4.2.1.3 Strom water retention value, $\mathrm{b} 3=(\mathrm{R}+\mathrm{E}) \times \mathrm{C} \times \mathrm{a}$

In this formula, $\mathrm{R}=$ retention basin $\$ 1,059.44 / \mathrm{m}^{3}$ (highest value) and $\$ 20.13 / \mathrm{m}^{3}$ retention pond (low cost), $\mathrm{E}=$ erosion mitigation value i.e. $\$ 13.66 / \mathrm{m}^{3}, \mathrm{C}=$ retention capacity $=$ 42.7 liter $/ \mathrm{m}^{2}[35]$ and $\mathrm{a}=$ roof area covered by farming.

As Mumbai is prone to urban flooding, this value assumes significance as it could bring in multiple co-benefits.

$$
\begin{aligned}
\mathrm{b}_{3}=(\mathrm{R}+\mathrm{E}) \times \mathrm{C} \times \mathrm{a} & =(1,059.44+13.66) \$ / \mathrm{m}^{3} \times 42.7 \mathrm{litre} / \mathrm{m}^{2} \times 4,032 \mathrm{~m}^{2} \\
& =184,752 \$(\text { Rs. } 13,736,311 /-)
\end{aligned}
$$

4.2.1.4 Air quality value, $\mathrm{b}_{4}=(\mathrm{g} / 12$ months $) \times(\mathrm{Hsg} \times \mathrm{asg}+\mathrm{Htg} \times \mathrm{atg}+\mathrm{Hd} \times \mathrm{ad})$

In this formula, Hsg, Htg, Hd represents the health benefits for short grass pollution absorption (0.0521 US\$ per $\mathrm{m}^{2}$ ), for tall herbaceous plant pollution absorption (0.0673 US\$ per $\left.\mathrm{m}^{2}\right)$, and deciduous plant pollution absorption $\left(0.0839 \mathrm{US} \$\right.$ per $\left.\mathrm{m}^{2}\right)$ per year respectively. Asg, atg, and ad are the areas under grasses, herbaceous crops, and deciduous plants respectively.

In India, vegetation grow all through the year. Considering the proposed RTF model to be semi-extensive with leafy vegetables and fruits, the average worth of annual pollutant removal health benefit for several types of RTF has been considered as 0.0678 US\$ per $\mathrm{m}^{2}$. $\mathrm{b}_{4}=(\mathrm{g} / 12$ months $) \times(\mathrm{Hsg} \times \mathrm{asg}+\mathrm{Htg} \times \mathrm{atg}+\mathrm{Hd} \times \mathrm{ad})=12 \mathrm{month} / 12 \mathrm{month} \times 0.0678 \$ / \mathrm{m}^{2}$ $\times 4,032 \mathrm{~m}^{2}=273.37 \$$ (Rs. 20,325/-)

4.2.1.5 Carbon sequestration value, $\mathrm{b}_{5}=\mathrm{Sd} \times \mathrm{ad}+\mathrm{Sg} \times \mathrm{ag}+\mathrm{Sf} \times \mathrm{af}$ In this formula, $\mathrm{Sd}, \mathrm{Sg}$, and $\mathrm{Sf}$ represent the carbon sequestration values by deciduous plants $(\$ 39.11 / \mathrm{ha})$, by grasses $(\$ 28.46 / \mathrm{ha})$, and by productive farming $(\$ 28.59 / \mathrm{ha})$, ad, ag, and af are the areas covered by deciduous crops, grasses, and productive agriculture respectively.

Considering RTF as semi-extensive with leafy vegetables and fruits, the estimation of carbon sequestration for the RTF works out to be $\$ 32.05 /$ ha.

$$
\mathrm{b}_{5}=\mathrm{Sd} \times \mathrm{ad}+\mathrm{Sg} \times \mathrm{ag}+\mathrm{Sf} \times \mathrm{af}=32.05 \$ / \mathrm{ha} \times 0.4032 \mathrm{ha}=12.92 \$(\mathrm{Rs} .961 /-)
$$


The survey results of the existing case studies and findings of the proposed model with the projection of RTF benefits as indicated in Fig. 8 suggest that utilization of organic waste through urban agriculture has positive environmental as well as financial implications in dense urban contexts. Further, the proposed model has high success potential in everexpanding cities like Mumbai, and can also be replicated in other Indian cities where municipal solid waste management has emerged as one of the biggest urban challenges from resource depletion and public health points of view.

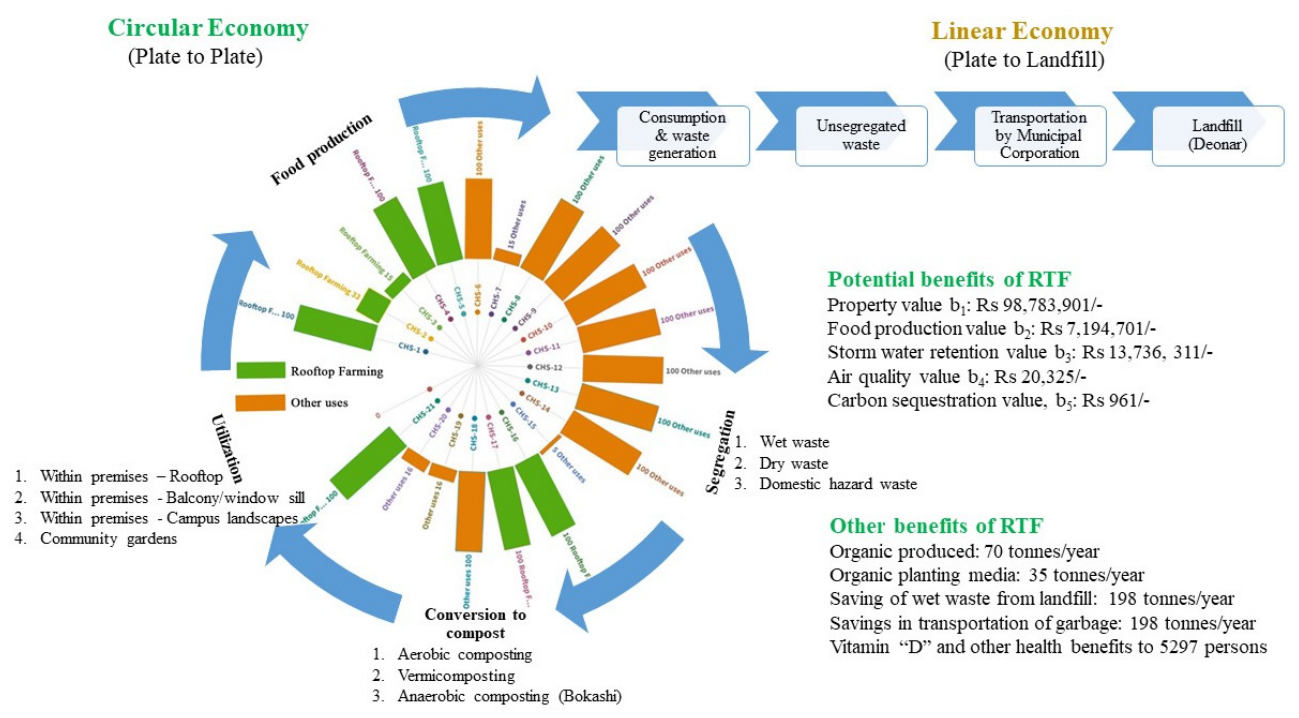

Figure 8: Proposed model for decentralized organic waste management in conjunction with UA and potential RTF benefits for the KE Ward, Mumbai.

\section{CONCLUSION}

Although utilization of organic waste in agriculture is common in rural India, it is rare in densely populated middle/upper-class city areas. This paper presented case studies in the Indian city of Mumbai to establish urban agriculture's current and potential capacity to consume and transform organic waste of a community into food as well as generate multiple environmental and economic benefits. The study shows how the inhabitants of Mumbai's dense neighbourhoods have evolved methods to segregate, compost, and grow food efficiently in the very limited confines of their city tenements. The concept of decentralized organic waste management in conjunction with UA emerges as a neighbourhood-level sustainable and replicable model. The study visualizes circular economy based on the reallife survey results and how the unsustainable plate-to-landfill approach can be successfully replaced by plate-to-plate practices, with production-consumption gainfully sustaining each other. The lessons learned can be used to encourage greater integration of urban agriculture with the urban economy, management, and governance. The findings of this research can be significant for policymakers, urban local bodies, city planners, private entrepreneurs, and others in integrating solid waste management with urban agriculture for a sustainable urban future. 


\section{REFERENCES}

[1] Ackerman, K., Conard, M., Culligan, P., Plant, R., Sutton, M.P. \& Whittinghill, L., Sustainable food systems for future cities: The potential of urban agriculture. The Econ. Soc. Rev., 45(2, Summer), pp. 189-206.a, 2014.

[2] Dhital, B., Sharma, A. \& Santosh Adhikari, S., Urban agriculture, waste management and food security, Nepal. IJEAB, 1(4), pp. 885-889, 2016.

[3] Tramhel, J.M., Using participatory urban design for the integration of organic solid waste management with urban agriculture: A case study in the Philippines. The University of Calgary, Faculty of Environmental Design, 2009.

[4] Kumar, L.A., Study of nitrate contamination in groundwater of Delhi, India. Asian J. Water Environ. Pollut., 10, pp. 91-94, 2013.

[5] Kawai, K. \& Tasaki, T., Revisiting estimates of municipal solid waste generation per capita and their reliability. J. Mater. Cycles Waste Manag., 18, pp. 1-13, 2016.

[6] CPCB, Status report on municipal solid waste management, 2013. http://www.cpcb.nic.in/divisionsofheadoffice/pcp/MSW_Report.pdfhttp://pratham.or g/images/paper_on_ragpickers.pdf.

[7] Sharholy, M., Āhmad, K., Mahmood, G. \& Trivedi, R.C., Municipal solid waste management in Indian cities: A review. Waste Manage., 28, pp. 459-467, 2008.

[8] Amritha, P.K. \& Kumar, P.A., Productive landscapes as a sustainable organic waste management option in urban areas. Environ. Dev. Sust., 2017.

[9] Aich, A. \& Kumar Ghosh, S., Organic fraction of municipal solid waste: A valuable source of green energy in India. Int. J. Energy Sec. Manag., 10, pp. 526-545, 2016.

[10] Yadav, A. \& Garg, V.K., Recycling of organic wastes by employing eiseniafetida. Bioresource Technol., 102(3), pp. 2874-2880, 2011.

[11] CNN, Poor suffer as Mumbai chokes on garbage dump haze, 2016. https://edition.cnn.com/2016/02/05/asia/mumbai-giant-garbage-dump-fire/. Accessed on: 3 Sep. 2021.

[12] Anastasiou, A. et al., The role of urban agriculture in urban organic waste management in The Hague, the Netherlands. Master's thesis, Wageningen University: Wageningen, 2014.

[13] Gertsakis, J. \& Lewis, H., Sustainability and the waste management hierarchy. www.helenlewisresearch.com.au/...TZW, 2003.

[14] Wascher, D., Kneadsey, M. \& Pintar, M., FoodMetres-food planning and innovation for sustainable metropolitan regions, 2015.

[15] Van Ewijk, S. \& Stegemann, J., Limitations of the waste hierarchy for achieving absolute reductions in material throughput. J. Cleaner Prod., 132, pp. 122-128, 2016.

[16] Ribić, B., Voća, N. \& Ilakovac, B., Concept of sustainable waste management in the city of Zagreb: Towards the implementation of the circular economy approach. J. Air Waste Manage. Assoc., 67(2), pp. 241-259, 2017.

[17] PEARL (Peer Experience and Reflective Learning), Urban Solid Waste Management in Indian Cities, NIUA (National Institute of Urban Affairs), 2015.

[18] Gupta, N., Yadav, K.K. \& Kumar, V., A review on the current status of municipal solid waste management in India. J. Environ. Sci., 37, pp. 206-217, 2015.

[19] Srivastava, V., Ismail, S.A., Singh, P. \& Singh, R.P., Urban solid waste management in the developing world with emphasis on India: Challenges and opportunities. Rev. Environ. Sci. Biotechnol., 14, pp. 317-337, 2015.

[20] Chatri, A. \& Aziz, A., Public-private partnerships in solid waste management: Potential and strategies. Athena Infonomics, 2012. 
[21] Sharma, B., Sarkar, A., Singh, P. \& Singh, R.P., Agricultural utilization of biosolids: A review on potential effects on soil and plant grown. Waste Manage., 64, pp. 117 $132,2017$.

[22] Van Veenhuizen, R., Cities Farming for the Future: Urban Agriculture for Green and Productive Cities, IDRC/RUAF: Ottawa, ON, 2006.

[23] Endres, A.B. \& Endres, J.M., Homeland security planning: What victory gardens and Fidel Castro can teach us in preparing for food crises in the United States. Food Drug Law J., 64, pp. 405-439, 2009.

[24] Warwick, H., Cuba's organic revolution. Forum Appl. Res. Pub. Policy, 16, pp. 5458, 2001.

[25] Small, G.E., Mcdougall, R. \& Metson, G.S., Would a sustainable city be self-sufficient in food production? Int. J. Design Nat. Ecodyn., 14(3), pp. 178-194, 2019.

[26] Herlekar, D.N., Urban Farming: How To Do It? Marathi Vidnyan Parishad: Mumbai, pp. 11-14, 2018.

[27] Vazquez, R., Cofie, O.O., Drechsel, P. \& Mensa-Bonsu, I.F., Linking urban agriculture with urban management: A challenge for policymakers and planners, 2002. The Sustainable City II, Urban Regeneration and Sustainability, eds C.A. Brebbia, J.F. Martin-Duque \& L.C. Wadhwa, WIT Press: Southampton and Boston, pp. 925-934, 2002.

[28] Joshi, R. \& Ahmed, S., Status and challenges of municipal solid waste management in India: A review. Cogent Environ. Sci., 2(1), 1139434, 2016.

[29] Kale, V.S. \& Joshi, V.U., Urbanization, human mobility and environmental conflicts in Mumbai and Chennai metropolitan regions, India, 2012. Human Mobility in Coastal Regions: The Impact of Migration and Temporary Mobilities on Urbanization, vol. 2, ed. A.M. Williams, Sapienza Università Editrice: Rome, pp. 129-160, 2012.

[30] Kedia, M., https://mickeykedia.github.io/mumbai_pop_map.html. Accessed on: 3 Sep. 2021.

[31] Ministry of Environment, Forests and Climate Change (MoEF\&CC), Solid Waste Management (SWM) Rules, Government of India: New Delhi, 2016.

[32] Mumbai Municipal Corporation (MMC) Act, 1888.

[33] The Greater Mumbai Cleanliness and Sanitation Bye-Laws, 2006.

[34] Tomalty, R. \& Komorowski, B., The Monetary Value of the Soft Benefits of Green Roofs, Canada Mortgage and Housing Corporation (CMHC): Montreal, 2010.

[35] Carter, T. \& Keeler, A., Life-cycle cost-benefit analysis of extensive vegetated roof systems. J. Environ. Manage, 87, pp. 350-363, 2008. 